\title{
HARDNESS AND ASSESSMENT OF ADHESION \\ OF MONOLAYER AND MULTILAYER NICKEL THIN FILMS ELECTROCHEMICALLY DEPOSITED ON SILICON SUBSTRATES WITH AND WITHOUT THE ULTRASONIC AGITATION
}

\author{
Jelena Lamovec \\ Vesna Jović \\ University of Belgrade, Institute for Chemistry, Technology and Metallurgy \\ The Microelectronic Technologies Department \\ Stevo Jaćimovski \\ Goran Jovanov \\ University of Criminal Investigation and Police Studies, Belgrade \\ Vesna Radojević \\ University of Belgrade, Faculty of Technology and Metallurgy \\ Jovan Šetrajčić \\ University "Union - Nikola Tesla", Faculty of Sport
}

\begin{abstract}
Composite systems of monolayer and multilayer nickel films electrochemically deposited on single crystal (100)-oriented silicon wafers were fabricated with and without the ultrasonic agitation. The hardness and adhesion behaviour of these composite structures were characterized by Vickers microindentation test. The dependence of composite microhardness and film adhesion on the structure of the film and mixing conditions of electrolyte were analysed. Mathematical models of Chicot-Lesage and Chen-Gao were applied to experimental data in order to obtain the film hardness and adhesion parameter respectively. It is confirmed that the mechanical properties of composite systems of nickel thin films on silicon substrate can be enhanced by formation of multilayer film structure by ultrasound-assisted electrodeposition and by reducing the layer thickness in the multilayer film.
\end{abstract}

Keywords: composite hardness, film adhesion, ultrasound-assisted electrodeposition, multilayer nickel films 


\section{Introduction}

Complex structures consisting of thin films on various substrates are important building blocks in fabrication of microelectromechanical (MEMS) devices. Development of reliable techniques for growing of metal monolayer or multilayer thin films is of great attention in the microsystem technologies (Morales, 2006, Datta, Landolt, 2000).

The integrity of microdevices will in many respects depend on mechanical properties such as hardness and adhesion. These mechanical properties depend on the film microstructure and the film-substrate interfacial structure. There are different techniques used to modify the interface structure in order to achieve better adhesion of the film such as introducing a new layer between the substrate and the film or modifying the film into a multilayered structure (Serre et al., 2005, Fritz, Mokwa, Schnakenberg, 2001).

Electrochemical deposition (ED) is a well-known technique, fully compatible with MEMS technologies. This technique gives many possibilities of obtaining and controlling the structure of materials which will directly affect the mechanical properties (Ebrahimi, Bourne, Kelly, Matthews, 1999).

Nickel films with fine-grained microstructure can easily be obtained by electrochemical deposition. Fine-grained films have better mechanical properties such as high yield strength, lower wear ratings, high hardness values and better corrosion resistance in comparison with nickel films of a standard grain size (Ebrahimi et al., 1999, Lamovec, Jovic, Randjelovic, Aleksic, Radojevic, 2008).

Using of ultrasound as a type of agitation together with electrochemical dep- osition (ED) technique can improve the structural and mechanical properties of the films such as grain size and shape, hardness and adhesion to the substrate, reduces internal stress and improves wear resistance (Walker, Walker, 1973).

One of the possibilities of using the ultrasound together with ED technique is to obtain the multilayer structure of the films, since it allows the change of the chosen film sub-layer structure (Niu, Wei, Yang, Hu, Yu, 2012, Yu et al., 2013).

A thin film on a substrate can be considered as a composite system whose mechanical properties depend on particular material properties of the film and of the substrate and also on composite system parameters such as adhesion, controlled residual stress, etc. Indentation hardness testing is a reliable method for evaluation of composite and film mechanical properties.

The response of the system to the indentation is so-called "composite hardness". As the thickness of the film is very small in comparison with the thickness of the substrate, the influence of the substrate must be included during the film hardness determination.

The measured composite hardness value is influenced by a number of factors such as film or film layer thickness, load or indentation depth, film and substrate hardness and their hardness ratio. Microhardness measurements are listed as a significant tool for assessing film adhesion on the substrates (Cammarata, 1994, Kaneko, Mizuta, Nishijima, Hashimoto, 2005, Magagnin, Maboudian, Carraro, 2003). 


\section{Composite hardness and adhesion models}

There is a large number of mathematical models developed for the purpose of calculating the absolute hardness of the film from the experimental measurements of composite hardness. They operate on a number of different principles and according to previous research of various types of composite systems, a selection of mathematical models for the systems being analysed was made (Chicot, Lesage, 1995, Lesage, Pertuz, Puchi-Cabrera, Chicot, 2006).

The composite hardness model of Chicot-Lesage (C-L) was found to be appropriate for experimental data analysis and film hardness calculation. This model is based on the analogy between the variation of the Young modulus of the reinforced composites in function of the volume fraction of particles and the variation of the composite hardness between the hardness of the substrate and hardness of the film (Chicot, Lesage, 1995).

$$
H_{C}=(1-f) /\left(1 / H_{S}+f \cdot\left(\frac{1}{H_{F}}-\frac{1}{H_{S}}\right)\right)+f \cdot\left(H_{S}+f \cdot\left(H_{F}-H_{S}\right)\right)
$$

where $H_{S}$ is hardness of the substrate of the film $\left(H_{F}\right)$ can be obtained as the and $H_{F}$ is hardness of the film. Hardness positive root of the next equation:

$$
\begin{aligned}
& A \cdot H_{F}^{2}+B \cdot H_{F}+C=0, \text { with } \\
& A=f^{2} \cdot(f-1) \\
& B=\left(-2 \cdot f^{3}+2 \cdot f^{2}-1\right) \cdot H_{S}+(1-f) \cdot H_{C} \\
& C=f \cdot H_{C} \cdot H_{S}+f^{2} \cdot(f-1) \cdot H_{S}^{2}
\end{aligned}
$$

The value of composite Meyer's index $(m)$ is calculated by a linear regression performed on all of the experimental data obtained for a particular film- $\ln d=m \cdot \ln P+b$ 
For each specific value of the composite Meyer's index $m$, the hardness of the film was calculated.

Evaluation of the adhesion properties of Ni thin films electrodeposited on Si (100) substrates was performed using the Chen-Gao model (Chen, Gao, 2000). This model introduces new expression named a function of indentation depth weight factor, which de- scribes the contribution of local hardness to composite hardness.

The relationship between the composite hardness $H_{C}$ of the film-substrate system and the function of indentation depth weight factor expressed through the critical reduced depth $b$, is given by the Eq. (6):

$$
H_{C}=H_{S}+\left[\frac{(m+1) \cdot t}{m \cdot b \cdot D}\right] \cdot\left(H_{F}-H_{S}\right)
$$

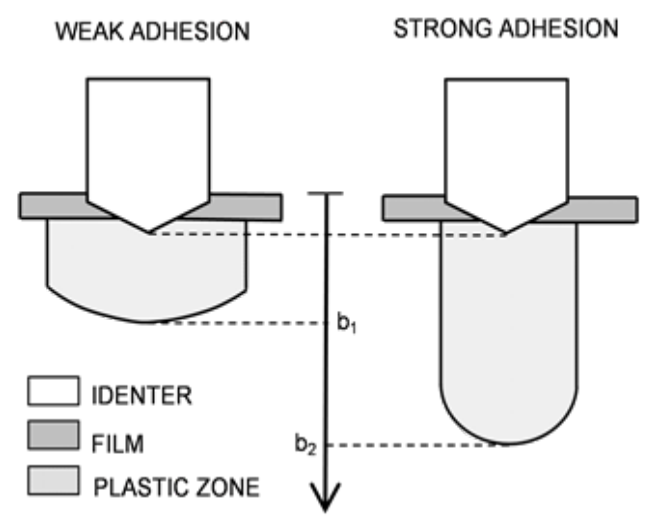

Fig. 1. Schematic representation of deformation associated with indentation in a coated substrate for a weak adhesion (left) and a strong adhesion (right)

The appropriate value for the power index $m$ is found to be 1.8 for the system of ED Ni films on $\mathrm{Si}(100)$ substrate (Chen et al., 2000). The film thickness is given with $t$ and $D$ is indentation depth. It was found that a large value of the critical reduced depth $b$ (ratio between the radius of the plastic zone beneath the indentation and the indentation depth) corresponds to good adhesion while low values indicate poor adhesion of the films as shown in Fig. 1.
By replacing the Vickers indent diagonal $d$ with $d=7 \cdot D$, and introducing the relation $\Delta H=H_{S}-H_{C}$, Eq. (6) may be reorganized as:

$$
\Delta H=\left[\frac{7 \cdot(m+1) \cdot\left(H_{S}-H_{F}\right)}{m \cdot b}\right] \cdot(t / d)
$$

The critical reduced depth $b$ can be calculated by using the Eq. (7) together with experimental values of $H_{C}, H_{P} t$ and $d$.

\section{Experimental procedure}

\subsection{Preparation of the Si substrates}

The substrates for the electrodeposition of Ni thin films were rectangular pieces of 4" (100)-oriented Si wafers. The plating base for the Si wafers were sputtered layers of $10 \mathrm{~nm} \mathrm{Cr}$ as the adhesion layer and 100 $\mathrm{nm} \mathrm{Au}$ as the nucleation layer (Fig. 2). 


\subsection{Ni film electrodeposition procedure}

Electrochemical deposition (ED) of $\mathrm{Ni}$ was performed under the dc-galvanostatic regime with the current density value maintained at $50 \mathrm{~mA} / \mathrm{cm}^{2}$, with and without the assistance of agitation in ultrasonic bath $(40 \mathrm{kHz})$. Nickel films were electrodeposited from laboratory-made sulphamate electrolyte consisting of $300 \mathrm{~g} / \mathrm{l}$ $\mathrm{Ni}\left(\mathrm{NH}_{2} \mathrm{SO}_{3}\right)_{2} \cdot 4 \mathrm{H}_{2} \mathrm{O}, 30 \mathrm{~g} / \mathrm{l} \mathrm{NiCl} \cdot 6 \mathrm{H}_{2} \mathrm{O}$, $30 \mathrm{~g} / 1 \mathrm{H}_{3} \mathrm{BO}_{3}$ and $1 \mathrm{~g} / \mathrm{l}$ saccharine.

The rates of the deposition with and without the presence of ultrasound were determined for the selected time interval (30 minutes), deposition area of 2 $\mathrm{cm}^{2}$ and current density value of $50 \mathrm{~mA} /$ $\mathrm{cm}^{2}$, by measuring the sample mass before and after the deposition and with the calculation of the average film thickness value. Deposition time was then determined for the projected thickness of the film of $10 \mu \mathrm{m}$. For comparison of properties of mono and multilayer films, monolayer thin films of Ni were electrodeposited first, with and without ultrasonic agitation. The multilayer Ni films were then obtained by alternate electrodeposition of ordinary $(\mathrm{O}-\mathrm{Ni})$ and ultrasonic-assisted nickel layers (U-Ni) for different deposition times for one layer (1 min and $30 \mathrm{~s}$ ).

\subsection{Observation of the multilayer film structure}

Examination of the multilayer film structure was performed by optical microscopy. Cross-section of the multilayer O-Ni/U-Ni film with thickness of 25 $\mu \mathrm{m}$ was prepared by cutting the sample vertically to the deposit surface and sealing with polymethyl methacrylate

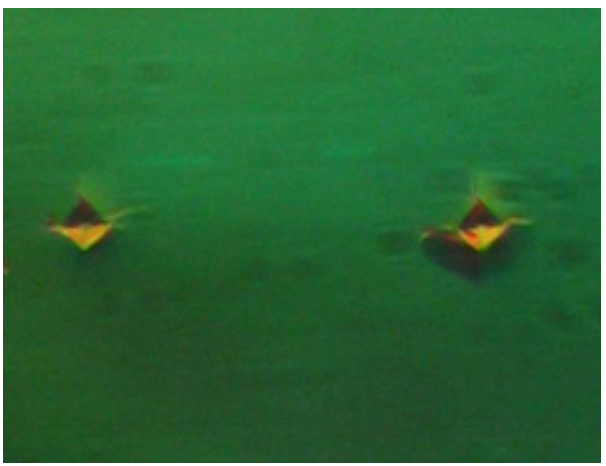

(PMMA) in the polishing mould. After mechanical polishing, the sample was etched in acidic solution $\mathrm{HNO}_{3}$ (conc.): $\mathrm{CH}_{3} \mathrm{COOH}$ (glac.) = 1:1 for $20 \mathrm{~s}$, followed by etching in $\mathrm{HCl}$ (conc.) for 1.5 hour (Rawdon, Lorentz, 1921).

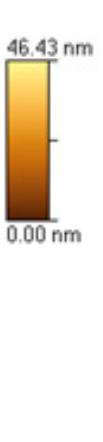

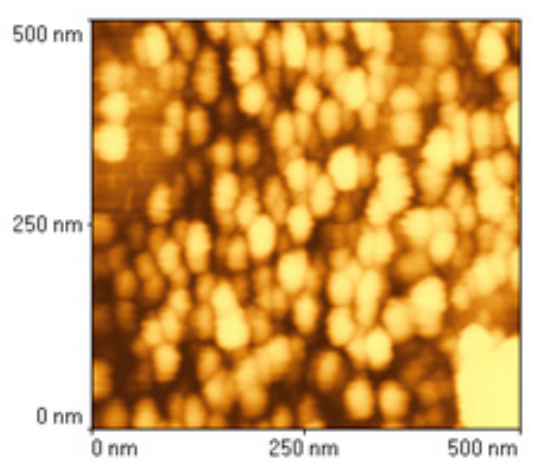

Fig. 2. Optical image of indents on the Si(100) substrate and AFM topography image of the plating base (Cr/Au) on Si(100) substrate

\section{Microindentation test}

The hardness of electrodeposited $\mathrm{Si}(100)$ substrate was characterized usmonolayer and multilayer $\mathrm{Ni}$ films on ing the Vickers microindenter "Leitz, 
Kleinharteprufer DURIMET I" with loads ranging from $0.049 \mathrm{~N}$ up to $1.96 \mathrm{~N}$ at room conditions. For each load, three best indentations were selected and their diagonals measured, from which the average composite hardness could be calculated (Lamovec et al., 2008).

\section{Results and discussion}

In order to see more clearly the differences in the microstructure of $\mathrm{Ni}$ films obtained by electrodeposition with and without the ultrasonic agitation by the optical microscopy, films with a layer thickness of 5 microns were deposited.
The multilayered structure of the Ni film is verified and clearly visible and shown in Fig. 3. The bright layers on the optical image represent the nickel layers deposited under ultrasonic agitation of electrolyte (U-Ni) and the dark ones are the ordinary deposited nickel layers (O-Ni).

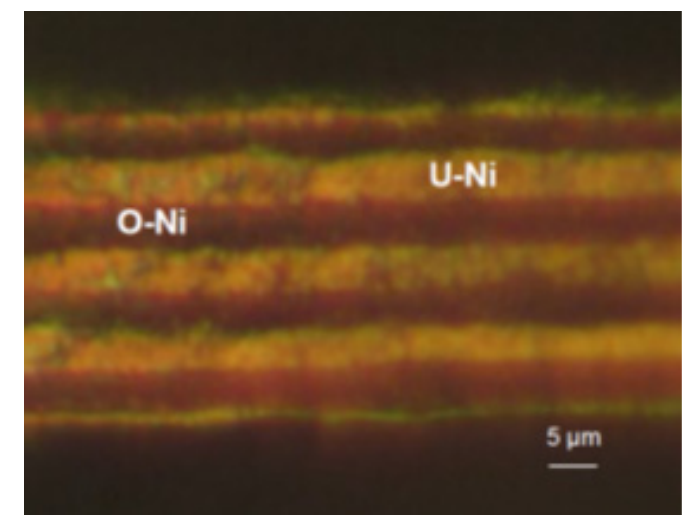

Fig. 3. Optical image of cross-section of multilayer $\mathrm{U}-\mathrm{Ni}$ / O-Ni film

According to the literature, it is considered that the grains of the U-Ni layer grow preferentially in the manner parallel to the substrate surface unlike the
O-Ni layer with columnar grains growth vertical to the substrate surface (Yu et al., 2013, Lamovec et al., 2018).

\section{Composite and film hardness}

Microhardness testing was performed first on uncoated substrate of single-crystal $\mathrm{Si}$ in order to calculate the substrate absolute hardness $\mathrm{H}_{\mathrm{s}}$. The value of load-independent microhardness for the Si substrate was calculated according to the Proportional Specimen Resistance (PSR) model of Li and Bradt as $\mathrm{H}_{\mathrm{S}}=6.49 \mathrm{GPa}(\mathrm{Li}, \mathrm{Bradt}, 1993$, Lamovec et al., 2008).

For the analysis and comparison of composite hardness, four samples were prepared. Two monolayer Ni films electrodeposited with and without the ultrasonic agitation were prepared first. The other two systems are multilayer composite systems with alternately electro- 
deposited $\mathrm{O}-\mathrm{Ni} / \mathrm{U}-\mathrm{Ni}$ films with differ- itation, the average values of measured ent layer thickness of $1 \mu \mathrm{m}$ and $500 \mathrm{~nm}$. diagonals and composite hardness, to-

For monolayer Ni films electrodep- gether with their standard deviations, osited with and without ultrasonic ag- are given for different loads (Table 1).

Table 1. The average values of measured diagonals, composite hardness and standard deviations for monolayer Ni films electrodeposited with and without ultrasonic agitation

\begin{tabular}{|l|lllll|}
\hline Sample & load $(\mathrm{N})$ & $\mathrm{dsr}(\mu \mathrm{m})$ & $\operatorname{stdev}(\mu \mathrm{m})$ & $\mathrm{Hc}(\mathrm{GPa})$ & $\operatorname{stdev}(\mathrm{GPa})$ \\
\hline $\mathrm{O}-\mathrm{Ni}$ & \multirow{2}{*}{0.049} & 6.01 & 0.22 & 2.51 & 0.18 \\
$\mathrm{U}-\mathrm{Ni}$ & & 5.80 & 0.10 & 2.71 & 0.09 \\
\hline $\mathrm{O}-\mathrm{Ni}$ & \multirow{2}{*}{0.098} & 7.46 & 0.16 & 3.27 & 0.14 \\
$\mathrm{U}-\mathrm{Ni}$ & & 7.23 & 0.11 & 3.50 & 0.11 \\
\hline $\mathrm{O}-\mathrm{Ni}$ & \multirow{2}{*}{0.245} & 10.66 & 0.11 & 4.00 & 0.09 \\
$\mathrm{U}-\mathrm{Ni}$ & & 10.36 & 0.23 & 4.20 & 0.19 \\
\hline $\mathrm{O}-\mathrm{Ni}$ & \multirow{2}{*}{0.392} & 13.65 & 0.15 & 3.90 & 0.08 \\
$\mathrm{U}-\mathrm{Ni}$ & & 13.04 & 0.23 & 4.28 & 0.15 \\
\hline $\mathrm{O}-\mathrm{Ni}$ & \multirow{2}{*}{0.490} & 14.64 & 0.22 & 4.24 & 0.12 \\
$\mathrm{U}-\mathrm{Ni}$ & \multirow{2}{*}{0.882} & 20.20 & 0.10 & 4.00 & 0.11 \\
\hline $\mathrm{O}-\mathrm{Ni}$ & \multirow{2}{*}{0.980} & 21.20 & 0.20 & 4.09 & 0.08 \\
$\mathrm{U}-\mathrm{Ni}$ & \multirow{2}{*}{1.961} & 29.66 & 0.39 & 4.13 & 0.11 \\
\hline $\mathrm{O}-\mathrm{Ni}$ & 29.19 & 1.39 & 4.27 & 0.40 \\
$\mathrm{U}-\mathrm{Ni}$ & & & & & \\
\hline
\end{tabular}

Change of the composite system the ED Ni films are with total thickness hardness $\left(H_{C}\right)$ with relative indentation of $10 \mu \mathrm{m}$ and they were all electrodepdepth $\left(h / t\right.$, indentation depth through osited with $50 \mathrm{~mA} / \mathrm{cm}^{2}$ current density. film thickness) is given in Fig. 4. All of

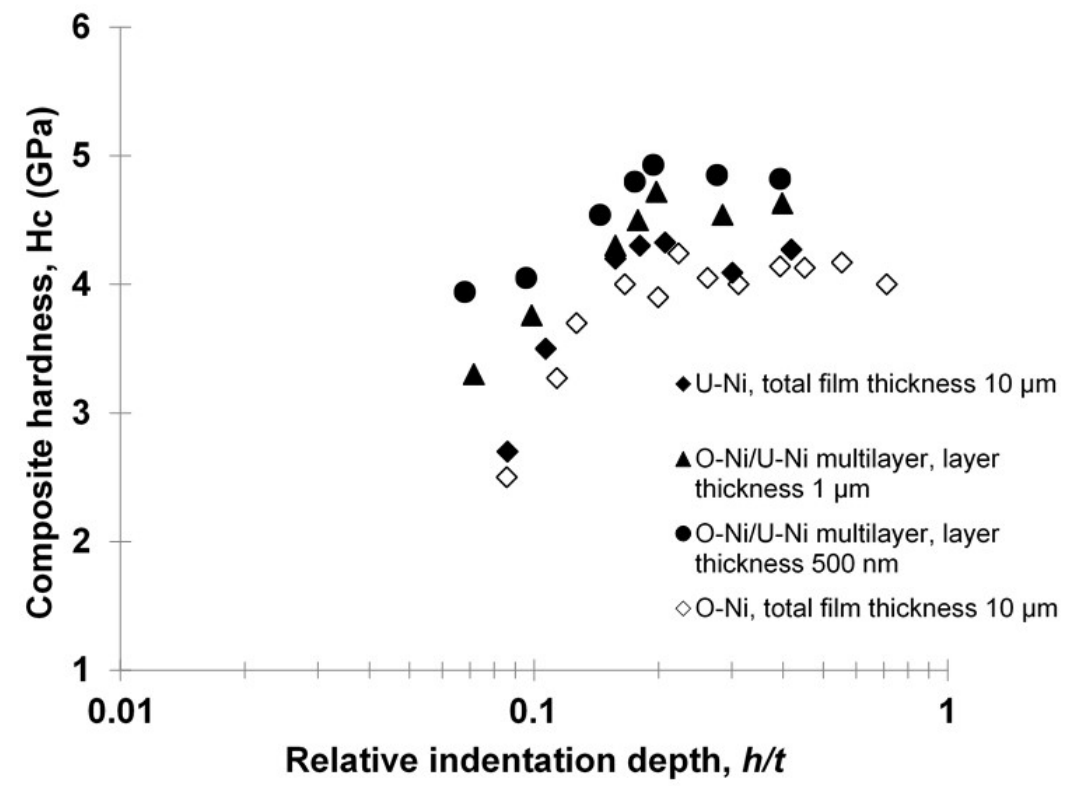

Fig. 4. Variation in the composite hardness $(\mathrm{HC})$ with relative indentation depth (h/t) for 10- $\mu$ m thick films on Si(100) substrates 
For shallow indentation depths (up to $10 \%$ of the film thickness, $0.01 \leq h / t \leq$ 0.1 ), only the film is subject to deformation. With increasing of the relative indentation depths increase $(h / t>0.1)$, the composite hardness changes in terms of approaching the hardness of the substrate $\left(H_{S}\right)$.

It is confirmed that electrodeposition supported by ultrasonic agitation leads to significant change in the microstructure (Fig. 3). Although the mean values of the measured diagonals and the calculated composite hardness for the monolayer films O-Ni and U-Ni do not differ much (Table 1 and Fig. 4), it can be said that electrodeposition in the presence of ultrasound can affect the mechanical properties in terms of their improvement.

In comparison with monolayer $\mathrm{Ni}$ films electrodeposited under ordinary conditions $(\mathrm{O}-\mathrm{Ni})$ and ultrasonic-assisted (U-Ni) films, higher values of the composite hardness are obtained for the multilayer ED films (especially for $0.1 \leq$ $\mathrm{h} / \mathrm{t} \leq 0.2$, when the hardness of the film in the hardness of the composite has a higher share). By reducing the thickness of the layer within the film and increasing the number of interfaces, it is possible to increase the composite hardness of the multilayer film - substrate composite system.

According to the model of Chicot-Lesage (C-L model), (Chicot, Lesage, 1995, Lesage et al., 2006), from measured indentation diagonal and calculated composite hardness, film hardness was calculated. The dependence of the film hardness $\left(H_{F}\right)$ on the relative indentation depth $(h / t)$ for all composite systems is shown in Fig. 5.

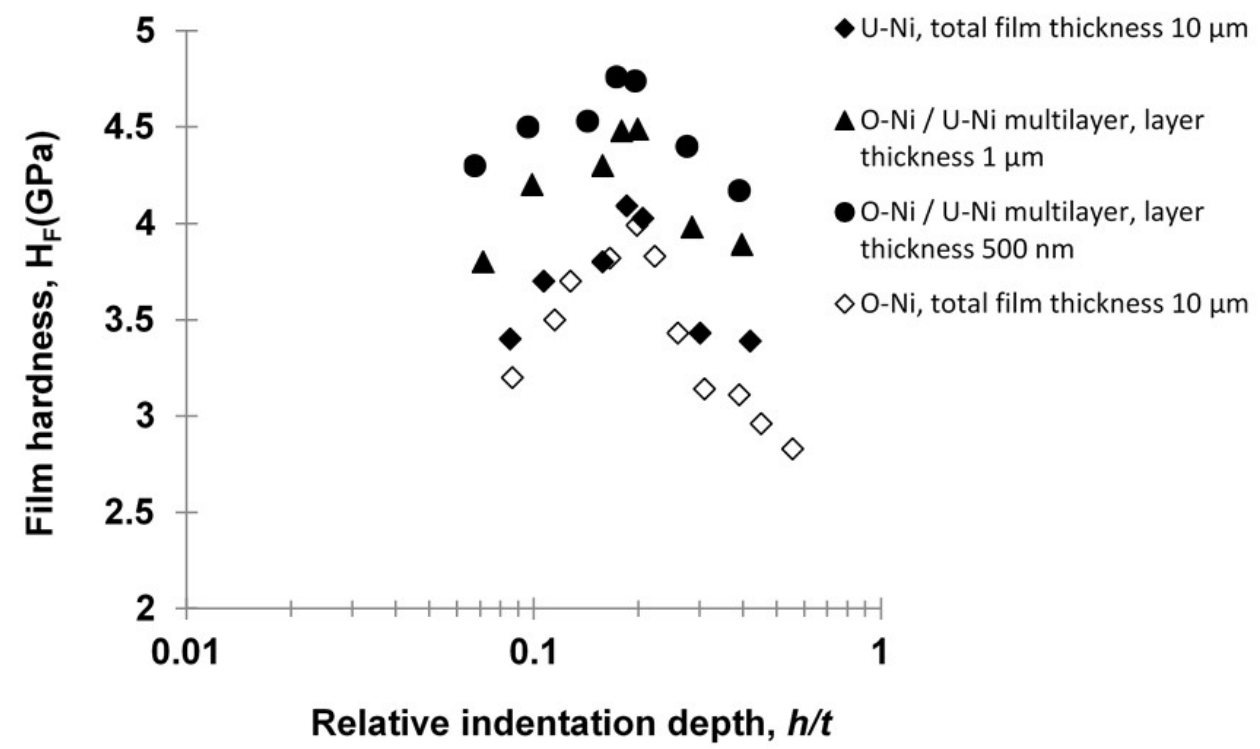

Fig. 5. Variation in the film hardness (HF) with relative indentati on depth $(h / t)$ for different ED Ni films with thickness of 10- $\mu \mathrm{m}$ deposited with current density value of $50 \mathrm{~mA} / \mathrm{cm} 2$

As shown in Fig. 5, the ultrasonic agitation affects the mechanical properties of monolayer and multilayer ED Ni films in terms of their slight improvement. This can be noticed by comparing the calculated values of the film hardness at low loads (for the relative indentation depth $0.1 \leq h / t \leq 0.2)$, when the influence of the 
film hardness in the measured composite hardness is more dominant.

The formation of the multilayer structure of the films achieved by alternate electrodeposition of $\mathrm{O}-\mathrm{Ni}$ and $\mathrm{U}-\mathrm{Ni}$ layers indicates possible further improvement of the mechanical properties compared to the monolayer films, in terms of increasing hardness compared to monolayer films.

By changing the thickness of the layer in the film, it is possible to change the structure and mechanical properties of the composite systems. With decreasing the layer thickness within the film, it is possible to achieve higher values of the film hardness. A large number of the interfaces in multilayer film structure are considered to serve as a barrier to dislocations, obstructing dislocation movement between the layers.
The model of Chicot-Lesage (C-L model) gives the possibility of calculating the composite Meyer's index $m$ that depends on the composite structure (especially of the substrate type). In Fig. 6 the composite Meyer's parameter $(t / d)^{m}$ is shown as the function of relative indentation depth $(h / t)$. It is the parameter that can express the difference in tendency of the composite hardness with the indentation load (Lamovec et al. 2008).

For the low loads $(h / t \leq 0.1)$, the response is of the film only and the highest value of the parameter was obtained for the system of multilayer Ni film with the layer thickness of $500 \mathrm{~nm}$. With increasing load, the parameter $(t / d)^{m}$ depends mostly on the substrate type. The behaviour of the parameter confirms that it is a substrate of the same type.

\section{Evaluation of film adhesion}

A composite hardness model of ChenGao (Chen, Gao, 2000) was used to evaluate the adhesion of ED Ni films on $\mathrm{Si}(100)$ substrates. The composite hardness of the film-substrate systems given in the form of Eq. (3) was used to calculate the critical reduced depth $b$. The film hardness results of applied C-L model were used. The values of critical reduced depth were calculated for every indent diagonal and then the average value was found. In Table 2 the results of the critical reduced depth $(b)$ calculation are given.
Increasing values of the critical reduced depth correspond to increasing adhesion. The microhardness difference decreases faster for a weaker adhesion when increasing the indentation load. It can be seen that using the ultrasound together with electrodeposition for obtaining the multilayer structure and also decreasing the layer thickness in the multilayer film lead to higher values of the film hardness and better adhesion properties.

\section{Conclusion}

Composite systems of electrochemically deposited (ED) Ni films on $\mathrm{Si}(100)$ substrates with and without the presence of ultrasound were prepared and analysed. It has been tried to obtain multilayer Ni films by alternating electrodepo- 
sition of ordinary and ultrasonic-assisted Ni layers. The current density value was maintained at $50 \mathrm{~mA} / \mathrm{cm}^{2}$, total thickness of the films was $10 \mu \mathrm{m}$ and thicknesses of the layers within the multilayer films were set as $1 \mu \mathrm{m}$ and $500 \mathrm{~nm}$.

The ultrasonic-assisted electrodeposition leads to changes in the microstructure of the Ni films. The ability to form a multilayer Ni films with the assistance of ultrasound was confirmed.

Due to the higher hardness of the $\mathrm{Si}$ substrate $(6.49 \mathrm{GPa})$ compared to $\mathrm{Ni}$ films, Ni films on Si (100) substrate can be thought of as "soft film on hard substrate" composite system type. The model of Chicot-Lesage (C-L model) was chosen for the analysis of experimental results of indentation and the film hardness was calculated for each indentation diagonal.

According to the results of composite hardness and film hardness measurements for electrodeposited monolayer $\mathrm{Ni}$ films, it can be concluded that the presence of ultrasound during the electrodeposition affects the mechanical properties in terms of their slight improvement.

The higher composite hardness and film hardness values are obtained for the multilayer ED Ni films (significant for values of relative indentation depth in the range of $0.1 \leq \mathrm{h} / \mathrm{t} \leq 0.2$, when the hardness of the film is more dominant in composite hardness value). Reducing the film thickness (from $1 \mu \mathrm{m}$ to 500 $\mathrm{nm}$ ) led to an increase in the composite hardness and the hardness of the multilayer film.

The parameter $(t / d)^{m}$ can express the difference in tendency of the composite hardness with indentation load. When the composite hardness tends to that of the film $(h / t \leq 0.1)$, the parameter $(t / d)$ ${ }^{m}$ is almost independent of the substrate type. Based on the behaviour of this parameter (the highest value of the parameter and the lowest value of the relative indentation depth), it can be concluded that the system with multilayer Ni film and the layer thickness of $500 \mathrm{~nm}$ has the best mechanical properties of all analysed systems. With increasing load, the influence of the substrate becomes the most important, and the parameter depends mostly on the substrate type.

Using of multilayer films is an effective way to release the stress across the interface of $\mathrm{Ni}$ films and the substrate. The distribution of stress at the interface is an important factor governing the adhesion of the film on the substrate. The adhesion assessment parameter based on the measured microhardness, named critical reduced depth, was used to evaluate the film adhesion. The multilayered $\mathrm{Ni}$ film with a $500 \mathrm{~nm}$ layer thickness has the highest value of this parameter, which points to better adhesion properties of this film compared to the others.

\section{Acknowledgements}

This work was funded by Republic of Serbia - Ministry of Education, Science and Technological Development through the projects TR 32008, TR 34011 and TR 34019. 


\section{References}

1. Cammarata, R.C. (1994). Mechanical properties of nanocomposite thin films, Thin Solid Films, 240: 82-87. https://doi.org/10.1016/0040-6090(94)90699-8

2. Chen, M., Gao, J. (2000). The adhesion of copper films coated on silicon and glass substrates, Modern Physics Letters B, 14(3): 103-108. https://doi.org/10.1142/ S0217984900000161

3. Chicot, D., Lesage, J. (1995). Absolute hardness of films and coating, Thin Solid Films 254: 123-130. https://doi.org/10.1016/0040-6090(94)06239-H

4. Datta, M., Landolt, D. (2000). Fundamental aspects and applications of electrochemical microfabrication, Electrochimica Acta, 45: 2535-2558. https://doi. org/10.1016/S0013-4686(00)00350-9

5. Ebrahimi, F., Bourne, G.R., Kelly, M.S., Matthews, T.E. (1999). Mechanical properties of nanocrystalline nickel produced by electrodeposition, Nanostructured materials, 11(3): 343-350. https://doi.org/10.1016/S0965-9773(99)00050-1

6. Fritz, T., Mokwa, W., Schnakenberg, U. (2001). Material characterisation of electroplated nickel structures for microsystem technology, Electrochimica Acta 47: 55-60. https://doi.org/10.1016/S0013-4686(01)00576-X

7. Kaneko, Y., Mizuta, Y., Nishijima, Y., Hashimoto, S. (2005). Vickers hardness and deformation of $\mathrm{Ni} / \mathrm{Cu}$ nano-multilayers electrodeposited on copper substrates, Journal of Material Science, 40: 3231-3236. https://doi.org/10.1007/s10853-0052690-4

8. Lamovec, J., Jović, V., Randjelovic, D., Aleksic, R., Radojevic, V. (2008). Analysis of the composite and film hardness of electrodeposited nickel coatings on different substrates, Thin Solid Films, 516: 8646-8654. http://dx.doi.org/10.1016/j. tsf.2008.06.035

9. Lamovec, J., Mladenović, I., Jović, V., Radojević, V., Jaćimovski, S., Jovanov, G. (2018). Obtaining and characterization of multilayer nickel thin films electrodeposited with the assistance of ultrasonic agitation, Zastita materijala 59(3): 394-400. http://idk.org.rs/wp-content/uploads/2018/09/6JLAMOVEC.pdf

10. Lesage, J., Pertuz, A., Puchi-Cabrera, E.S., Chicot, D. (2006). A model to determine the surface hardness of thin films from standard micro-indentation tests, Thin Solid Films 497: 232-238. https://doi.org/10.1016/j.tsf.2005.09.194

11. Li, H., Bradt, R.C. (1993). The microhardness indentation load/size effect in rutile and cassiterite single crystals, J. Mater. Sci., 28: 917- 926. https://doi. org/10.1007/BF00400874

12. Magagnin, L., Maboudian, R., Carraro, C. (2003). Adhesion evaluation of immersion plating copper films on silicon by microindentation measurements, Thin Solid Films, 434: 100-105. https://doi.org/10.1016/S0040-6090(03)00469-3

13. Morales, L. A. (2006). Electrodeposited metal matrix nanocomposites as thin films and high aspect ratio microstructures for MEMS, SU Doctoral Dissertations. 1399. https://digitalcommons.lsu.edu/gradschool_dissertations/1399 
14. Niu, Y., Wei, J., Yang, Y., Hu, J., Yu, Z. (2012). Influence of microstructure on the wear mechanism of multilayered $\mathrm{Ni}$ coating deposited by ultrasound-assisted electrodeposition, Surface \& Coatings Technology, 210: 21-27. https://doi. org/10.1016/j.surfcoat.2012.08.015

15. Rawdon, H.S., Lorentz, M.G. (1921). Metallographic Etching Reagents: II. For copper alloys, nickel and the alpha alloys of nickel, Scientific papers of the bureau of standards, 17:666-658. https://nvlpubs.nist.gov/nistpubs/ScientificPapers/ nbsscientificpaper435vol17p635_A2b.pdf

16. Serre, C., Yaakoubi, N., Perez-Rodriguez, A., J. R. Morante, J.R., Esteve, J., Montserrat, J. (2005). Electrochemical deposition of $\mathrm{Cu}$ and $\mathrm{Ni} / \mathrm{Cu}$ multilayers in $\mathrm{Si}$ Microsystem Technologies, Sensors and Actuators A, vol. 123-124: 633-639. https://doi.org/10.1016/j.sna.2005.04.022

17. Walker, C.T., Walker, R. (1973). Effect of ultrasonic agitation on some properties of electrodeposits, Electrodeposition and Surface treatment, 1: 457-469. https:// doi.org/10.1016/0300-9416(73)90029-1

18. Yu, Z., Zhu, Y., Niu, Y., Yang, Y., Wei, J., Ding, W. (2013). Preparation and adhesion performance of multilayered Ni coatings deposited by ultrasonic-assisted electroplating, Journal of adhesion science and technology, 27(2): 136-142. https://doi.org/10.1080/01694243.2012.701512

\title{
TVRDOĆA I PROCENA ADHEZIJE JEDNOSLOJNIH I VIŠESLOJNIH TANKIH FILMOVA NIKLA ELEKTROHEMIJSKI DEPONOVANIH NA SILICIJUMSKIM PODLOGAMA SA I BEZ ULTRAZVUČNOG MEŠANJA
}

\author{
Jelena Lamovec \\ Vesna Jović \\ Centar za mikroelektronske tehnologije \\ Institut za hemiju, tehnologiju i metalurgiju \\ Univerzitet u Beogradu \\ Stevo Jaćimovski \\ Goran Jovanov \\ Kriminalističko-policijski univerzitet, Beograd \\ Vesna Radojević \\ Tehnološko-metalurški fakultet Univerziteta u Beogradu \\ Jovan Šetrajčić \\ Fakultet za sport Univerziteta „Union - Nikola Tesla”, Beograd
}


Sažetak: Formirani su kompozitni sistemi od jednoslojnih i višeslojnih filmova nikla elektrohemijski deponovanih sa i bez ultrazvučnog mešanja na pločicama od monokristalnog silicijuma orijentacije (100). Tvrdoća i adhezija tih kompozitnih struktura su okarakterisane testom mikrotvrdoće po Vikersu. Analizirana je zavisnost mikrotvrdoće kompozita i adhezije filma od strukture filma i uslova mešanja elektrolita. Matematički modeli Šiko-Lezaža i Čen-Gaoa su primenjeni na eksperimentalne podatke kako bi se dobile vrednosti tvrdoće filma i parametra adhezije. Potvrđeno je da se mehanička svojstva kompozitnih sistema sastavljenih od tankih filmova nikla na silicijumskoj podlozi mogu poboljšati formiranjem višeslojne strukture filmova, primenom ultrazvučnog mešanja pri elektrodepoziciji i smanjenjem debljine sloja u višeslojnom filmu.

Ključne reči: kompozitna tvrdoća, adhezija filma, ultrazvučno potpomognuta elektrodepozicija, višeslojni film nikla. 